\title{
The Institutionalisation of Corporate Social Responsibility Reporting
}

\author{
Charl de Villiers ${ }^{\#}$ and Deborah Alexander* \\ ${ }^{\text {\#}}$ The University of Waikato and University of Pretoria \\ *The University of Auckland
}

${ }^{\#}$ Corresponding Author

Charl Johannes de Villiers

Professor

Department of Accounting

The University of Waikato and University of Pretoria

Private Bag 3105

Hamilton, 3240, New Zealand

Phone: +6478384236

E-mail: cdev@ waikato.ac.nz

* Deborah Ann Alexander

Department of Accounting and Finance

The University of Auckland

E-mail: d.alexander@auckland.ac.nz

Phone: +6499239415

We thank the Accounting and Finance Association of Australia and New Zealand for financial assistance for this project. We thank the editor and participants at the $8^{\text {th }}$ Australasian CSEAR and seminars at the University of Canterbury, University of Bologna, University of South Australia, and The University of Waikato; reviewers and participants at the APIRA conference 2010 and the EAA conference 2011; also Amanda Ball, Russell Craig, Claire Dambrin, Cameron Graham, Jill Hooks, Stephen Jollands, and Chris van Staden; as well as Michael Jones and two anonymous reviewers for helpful comments and suggestions. 


\begin{abstract}
This study examines corporate social responsibility reporting (CSRR) structures through a comparison of the disclosures in two countries with different social issues. The analysis is guided by a focus on the legitimisation offered by isomorphism. We compare the 2007 annual report and website (including standalone report) CSRR of a matched sample of 18 Australian and 18 South African mining companies. Among the 30 comparisons of disclosure patterns, 29 show no difference. We also provide examples of specific disclosures that show a remarkable level of similarity in CSRR and in the CSRR management structures adopted in the two countries. Our findings show similar overall patterns of CSRR in diverse settings, while differences in CSRR content at a more detailed level remain. For example, companies refer to the applicable national regulations and rules; as well as to their specific local communities. These findings provide evidence that the same reporting templates are used in CSRR globally. There is evidence to suggest that CSRR is institutionalised through professionalization and other means, suggesting a need to interpret CSRR characteristics and patterns as a reflection of global CSRR templates. Management intent or company-specific characteristics, such as social and environmental performance, do not necessarily drive CSRR patterns.
\end{abstract}

Keywords - Corporate Social Responsibility, Environmental disclosure, Social disclosure Paper type - Research paper 


\section{INTRODUCTION}

Corporate social responsibility reporting $(\mathrm{CSRR})^{[1]}$, the disclosure of social and environmental information in annual reports and on websites, is gaining in popularity (KPMG, 2011). Social and environmental disclosures are mostly voluntary and therefore the CSRR literature has focussed much attention on the reasons why companies disclose (e.g. Clarkson, Li, Richardson, \& Vasvari, 2008; Hackston \& Milne, 1996; Cowen, Ferreri, \& Parker, 1987). Size and industry are leading indicators of companies' likelihood to disclose, as are negative environmental issues (Deegan \& Rankin, 1996), specific pressure groups (Deegan \& Gordon, 1996; Blomquist \& Deegan, 2006), and media attention (Brown \& Deegan, 1998). In these prior studies, the attention is on the content of CSRR.

Using a new institutional theory framework (NIT), we are interested in the overall structure of CSRR, both in terms of the structure of the disclosures made and in terms of the management structures that underlie both the disclosures and the process of disclosure. We examine the CSRR structures and patterns of size matched mining companies in two countries, Australia and South Africa, where social and environmental issues, pressure groups, and media attention are different. We analyse the overall structure of CSRR in the two samples by comparing the number of sentences disclosed in different categories of CSRR, first overall, then in smaller sub-categories, then in terms of the tone of the sentences (positive, negative, or neutral), next in terms of where the sentences are disclosed (financial report, rest of the annual report, or website), and also by quality scores (financial, quantitative, specific, or declarative). In addition, we cite specific examples of similar disclosures, as well as disclosures that reveal similar CSRR board, committee, and management structures in the two countries. Finally, we provide an analysis of differences in CSRR. 
As far as we can ascertain, our focus on CSRR structure represents a unique contribution to the literature. For example, our study goes beyond Aerts, Cormier, and Magnan (2006), who find evidence that mimetic isomorphism could be a factor explaining environmental reporting. We expand the theoretical framework to include other forms of isomorphism, expand the disclosure media to include both annual reports and websites, expand types of disclosures to include both social and environmental, and move the focus from content of disclosure to patterns and structures of disclosure.

Our findings indicate that, even though the two countries display different social characteristics, the CSRR structures and patterns of mining companies are remarkably similar. Differences in CSRR appear to be confined to matters of detail, for example referring to the specific local community in Australia or the specific local community in South Africa. The differences fit within similar overall CSRR structures and patterns. These findings suggest that global CSRR patterns are being adopted in very different corners of the globe. The implication is that when interpreting CSRR, the observer, be they pressure groups, regulators, or researchers, should take into consideration that the overall structure, pattern, and emphasis of CSRR are not necessarily reflecting corporate priorities and intentions, but may be driven by a desire to follow global templates. Overall, this paper contributes to the CSRR literature by drawing attention to the distinction between CSRR content and CSRR patterns, and thus providing a new way of interpreting and theorizing voluntary CSRR.

\section{BACKGROUND}

The mining industry is a significant provider of employment and wealth. South Africa and Australia are among the top five producers of mineral commodities. According to the International Marketing Council (IMC) of South Africa (2009), "South Africa accounts for over $10 \%$ of world gold production, and is the leading producer of platinum, manganese, titanium, chrome, zirconium and vanadium... It is also South Africa's biggest employer, with 
around 460,000 employees and another 400,000 employed by the suppliers of goods and services to the industry". According to the Minerals Council of Australia (2009), the Australian minerals industry is ranked first in the world for the production of bauxite, second for uranium and third for gold and diamonds. In the financial year 2008-09 the minerals industry contributed $8 \%$ of Australian GDP. The industry employs about 133,200 people directly and 200,000 indirectly.

Mining provides economic benefits, but has major environmental and social effects, such as land use, exhaustion of non-renewable resources, and worker health and safety concerns (Azapagic, 2004). At a time when sustainability issues are growing in importance (Schaltegger et al., 2013; Lawrence et al., 2013; Glennie and Lodhia, 2013; Samkin, 2012; De Klerk and De Villiers, 2012), these effects can be expected to influence CSRR through negative environmental issues, pressure groups, and media attention.

Large mining companies are reported to disclose CSRR content heterogeneously (Jenkins \& Yakovleva, 2006; Perez \& Sanchez, 2009). However, note that these studies do not distinguish between CSRR content and CSRR patterns. The differences in CSRR content noted by these studies may be due to differences in stakeholders for each mining company. Environmental issues, such as water, energy and biodiversity conservation; and greenhouse gas emissions, are of most interest to insurers, local communities, local authorities, governments and NGO's (Azapagic, 2004). Social issues, such as employment, skills development, and health and safety, are of most interest to employees and trade unions (Azapagic, 2004). Thus, different stakeholders require different disclosures. However, note that it is in theory possible to fit differing CSRR content into similar CSRR patterns. Something not explicitly investigated in the prior literature.

A KPMG (2006) survey found that more than $90 \%$ of the 50 largest mining companies in the world include sustainability information in their annual reports and all of them had 
sustainability information on their websites. The KPMG (2006) survey shows the reporting practices of companies, including from Australia (5 companies surveyed) and South Africa (6 companies surveyed), however, the survey uses a small sample size, and some companies in the study are cross-listed and are, therefore, influenced by stakeholders in other countries. Therefore our study, that does not contain any cross-listings, will provide a more reliable means of comparison than the KPMG (2006) survey.

\section{AUSTRALIA AND SOUTH AFRICA: DIFFERENCES AND SIMILARITIES}

There are many substantial social differences between Australia and South Africa, suggesting that the environmental and social issues, the pressure groups, and the media attention that influence CSRR will be different. We highlight some quantifiable social differences here to illustrate the point.

The World Bank classifies Australia as "high income OECD" with a gross national income per capita of US\$29,243 in 2006 and South Africa as "upper middle income" with US\$5,410 (World Bank, 2009). The infant mortality rate was 49.6 per 1,000 live births in South Africa and 4.8 in Australia. Life expectancy at birth was 50.7 years in South Africa and 80.3 years in Australia.

There are 5.2 million people with HIV/AIDs in South Africa (Avert, 2009). Almost one third of women aged 25-29, and over a quarter of men aged 30-34 have HIV (Avert, 2009). These infection rates among the working age population affect the social and economic spheres severely. Over 250,000 South Africans died of AIDS in 2008. As a consequence, the orphaned children are typically left without assets or incomes. There are already 1.4 million AIDS orphans and $20 \%$ of these children do not attend school (Avert, 2009). On a population-wide basis, the HIV prevalence is estimated at $18.2 \%$ in South Africa versus $0.08 \%$ in Australia. 
The South African mining industry can be implicated in these social concerns. It attracts thousands of male workers from poor, remote regions. They live in all-male hostels separated from their families. Consequently, the sex industry flourishes around mines and increases the spread of HIV. Mining companies have implemented prevention programmes for miners and some now provide family accommodation (Avert, 2009).

The official unemployment rate in South Africa was $23.1 \%$ in the second quarter of 2009 (Statistics South Africa, 2009). However, closer inspection shows that only $44.7 \%$ of 15-64 year olds were employed and categories such as "discouraged work seekers" were not included in the unemployment percentage. Of those who are classified as "employed" in these statistics, $17.0 \%$ are in the "informal sector", signifying that they do not have regular jobs with regular incomes. In Australia, the unemployment rate was 5.9\% in July 2009 with a labour participation rate of $65.3 \%$ (HRM Guide, 2009). Employment status influences social wellbeing.

The large differentials in income, health and unemployment statistics show some of the social differences between the two countries. Both countries are democracies with freedom of expression and the media. This enables stakeholders to be heard and to exert the kind of pressure to potentially change CSRR through political means, by making public speeches, by organising protest marches and strikes, and by getting their message across through the media, e.g. radio and television news, editorial programmes, and newspapers (Brown \& Deegan, 1998). Because of the social differences between Australia and South Africa, we believe that different stakeholders are better placed to apply pressure on mining companies in each country. For example, in South Africa social needs and priorities may empower stakeholder groups who aim to increase employment opportunities more than stakeholder groups with an environmental agenda. Specifically, trade unions such as Cosatu (Congress of South African Trade Unions) might be stronger than Greenpeace. Cosatu was important 
during the 'struggle' years (1980s) and was one of the three most important transition negotiators during the early 1990s (the other two being the African National Congress (ANC, the governing party today) and the South African Communist Party). In 2008, Cosatu declared that the president of South Africa and of the ANC, Thabo Mbeki, followed policies that did not benefit ordinary workers. Cosatu revealed its power by replacing Mbeki with their preferred candidate, Jacob Zuma. Trade unions, such as Cosatu, are more interested in social information than environmental information (Azapagic, 2004). The trade union movement is said to be strong in Australia and if the strength of trade unions can be judged by the pay and condition of workers, then Australia's trade unions' ability to apply pressure and influence can be argued to be stronger than their South African counterparts. Whether we believe Australian or South African trade unions to be better at applying pressure, few would argue that there are differences between the two countries.

Environmental stakeholders might be stronger in Australia. As an indication, the Greenpeace website 'country' list includes Australia, but not South Africa, indicating their relative importance to Greenpeace. Companies pay attention to powerful stakeholders and respond with meaningful disclosure strategies, whereas less powerful stakeholders are ignored or treated with short symbolic disclosures (Neu, Warsame, \& Pedwell, 1998).

Prior research has shown community pressure groups or stakeholders to have a major influence on corporate social disclosures (Tilt, 1994; Gray, Owen, \& Adams, 1996). Deegan and Gordon (1996) specifically connect the increase in environmental organisation membership with corporate environmental disclosures. According to Schepers (2006), NGOs often target corporations. Deegan and Blomquist (2006) provide a specific example by linking the environmental reporting of an Australian mining company with World-Wide Fund for Nature (WWF) influence. Therefore, local stakeholders with local concerns should influence CSRR. Georgakopoulos and Thomson (2008) conceptualise CSRR as a contest 
whereby stakeholders engage with companies, regulators, political institutions and the general public. The contest is mediated by issue amplifiers, such as the media. Media attention specifically influences CSRR content, as shown by Ader (1995), Brown and Deegan (1998), and Patten (2002). Deegan, Rankin, and Tobin (2002) also show a link between media attention on specific social issues and social disclosures by the mining company BHP. Overall, the prior literature suggests that local stakeholders influence CSRR content. Therefore we might expect CSRR in the two countries to be different at the level of specific disclosures. However, we are not sure if these influences permeate to the level of the overall patterns of CSRR.

The capital markets that both countries' listed mining companies deal with are similar. Shareholders and lenders hold mining companies in both countries to similar standards. IFRS accounting standards are mandatory in both countries. Listed companies also face similar requirements for the disclosure of additional information. Good corporate governance practice and the disclosure thereof are encouraged in guidelines in both countries (King II in South Africa and the ASX Corporate Governance Guide in Australia). Both countries have considerable social and environmental legislation, e.g. requirements regarding provisions for rehabilitation after mining operations cease. These similarities in disclosure and other rules lead to similarities in CSRR. For example, if mines did not have to rehabilitate after operations cease, there would be no environmental liability to disclose. Similar rules also cause similar concerns among stakeholders, e.g., shareholders may need information regarding the impact of employment or environmental rules on future cash flows.

Another interesting similarity is that the same mining company, BHP Billiton (not in our sample, because it is listed in both countries), is the largest in both Australia and South Africa. BHP (Australian) and Billiton (South African) merged, with the result that both Australians and South Africans claim the company as their own. Not only is BHP Billiton the 
largest, but the company is also considered a leader among mining companies in social and environmental reporting (Perez \& Sanchez, 2009).

Mining companies in both countries may also share the same shareholders and international customers, suggesting similar pressures to conform to CSRR norms. Similarities also extend to professional management. Managers, accountants, and public relations professionals of large mining companies in both countries are typically business degree graduates, often with MBAs and professional qualifications, such as Chartered Accountancy.

B.Com, MBA, and CA curricula tend to be similar everywhere, because universities and professional bodies follow the best examples in the world. These programmes are also all implicitly based on the same neo-classical economic underpinnings. Therefore, managers and professionals in mining companies in both countries can be expected to base decisions, including CSRR decisions, on similar principles.

\section{THEORY}

NIT constitutes a rich body of ideas that can be applied in many different ways to steer research and interpret findings. In this paper, we limit ourselves to the use of the concept of isomorphism to guide our examination of CSRR patterns. Organisations experience pressures that lead them to adopt rules and structures to enhance legitimacy (DiMaggio \& Powell, 1983; Deephouse, 1996). Thus organisations become isomorphic with their environment and therefore organisations that occupy a similar position in a field tend to adopt similar rules and structures. This summarises the structuralist (as opposed to the agency) view of NIT, where structure is examined and not beliefs, because structures reflect beliefs (Heugens \& Lander, 2009). Structures are seen to lead to change towards conformance that agents find difficult to resist. The structuralist approach is appropriate here, because our method of content analysis does not allow us to directly examine beliefs. We now turn to a discussion of isomorphism 
and how it might explain changes in companies' CSRR, as well as changes in the field of CSRR. Note that a field can be defined in different ways, but that we focus on the field of CSRR.

DiMaggio and Powell (1983) identify three types of isomorphic forces, namely mimetic, coercive and normative. As the adjectives suggest, mimetic refers to companies benchmarking (or copying) each other, coercive refers to companies being forced into a course of action, and normative refers to the professionalization of norms (Dacin, 1997; Haveman, 1993). CSRR patterns are potentially influenced by each of the three types of isomorphic forces as explained below.

Large multinational companies benchmark against their peers and smaller companies benchmark against industry leaders, e.g. BHP Billiton. Thus individual mining company CSRR change and the CSRR field converges over time by way of mimetic isomorphism.

The capital markets operate along similar lines in Australia and South Africa and cause similar corporate pressures that can potentially result in coercive isomorphism. Legislation of mining company practice and disclosure in both Australia and South Africa focus on very similar issues. For example, before a mining licence is issued, the authorities require an approved environmental rehabilitation programme, implying a rehabilitation liability, leading to environmental disclosure in the annual report. However, stakeholders, such as Greenpeace or Cosatu, can also apply pressure that can lead to coercive isomorphism and influence CSRR change in different directions in the two countries. As examples, Australian mining companies might experience more pressure from Greenpeace (than South African companies); and South African companies might experience more pressure regarding employment equity. ${ }^{[2]}$ These pressures create the conditions for Australian CSRR patterns to emphasise environmental issues and for South African CSRR patterns to emphasise employment equity. These are only some examples of the CSRR pattern differences that may 
exist between Australian and South African mining companies, because of the differences in local stakeholder pressures.

Normative isomorphism takes place when companies internalise the norms that derive from the professionalization of a field (DiMaggio \& Powell, 1983; Mizruchi \& Fein, 1999; Suddaby \& Viale, 2011). Companies seek professional CSRR guidance in the form of consultants and guidelines, e.g., the GRI guidelines. GRI's normative nature is revealed in the first sentence of the executive summary: "The Sustainability Reporting Guidelines help organizations determine what they should report on and how they should report it." (GRI, 2009b: 1, emphasis added). Companies increasingly follow the GRI guidelines (KPMG, 2008, 2011), because they believe this to be the 'right thing to do'. Of course, we cannot rule out the possibility that some companies also follow GRI because they are not sure what to disclose (suggesting mimetic isomorphism) or because others pressurise them into following GRI (suggesting coercive isomorphism).

A new field often creates much innovation and uncertainty. Convergence tends to commence when companies respond to this uncertainty by copying others (mimetic isomorphism). Over time, increased regulation and societal expectations in the field cause coercive isomorphism. Later on, as the field matures, normative isomorphism through professionalization becomes an important factor (Suddaby \& Viale, 2011). However, the three types of isomorphic forces "can and, generally do, operate simultaneously" (Tuttle \& Dillard, 2007: 392). Apart from organisational change, field level change may be caused by professionalization (Suddaby \& Viale, 2011). Therefore it might be expected that the field of CSRR will eventually reach a phase where normative isomorphism predominates, but where elements of mimetic and coercive isomorphism remain. Normative isomorphism can potentially cause both companies to change and the field of CSRR to change over time. 
Table 1 explains in more detail the general transition of a field from a formative phase (mimetic and coercive isomorphism) to a more mature phase (normative isomorphism) through an exposition of the phases, characteristics of the phases, the forces or pressures involved, and the typical company responses and processes involved (refer to the first five rows).

Table 1. The development of the field of CSRR - homogeneity increases with maturity

\begin{tabular}{|c|c|c|c|}
\hline & $\begin{array}{c}\text { MIMETIC } \\
\text { ISOMORPHISM }\end{array}$ & COERCIVE ISOMORPHISM & $\begin{array}{l}\text { NORMATIVE } \\
\text { ISOMORPHISM }\end{array}$ \\
\hline PHASE & Formative phase & Formative phase & Field Matures \\
\hline CHARACTERISTICS & Environmental uncertainty & $\begin{array}{l}\text { Political Influence and the } \\
\text { problem of legitimacy }\end{array}$ & $\begin{array}{l}\text { Professionalization and } \\
\text { standardisation }\end{array}$ \\
\hline FORCES & Uncertain how to respond & $\begin{array}{l}\text { External pressure from } \\
\text { institutions the organization is } \\
\text { dependent on } \\
\text { internal pressure to conform to } \\
\text { societal expectations }\end{array}$ & $\begin{array}{l}\text { Professionals receive } \\
\text { similar training and } \\
\text { interact with other } \\
\text { professionals, socializing } \\
\text { them into similar views }\end{array}$ \\
\hline RESPONSE & Copy superior performer & Conformance to demands & $\begin{array}{l}\text { Conformance to } \\
\text { expectations }\end{array}$ \\
\hline PROCESSES & $\begin{array}{l}\text { Benchmarking } \\
\text { Identify best practices }\end{array}$ & $\begin{array}{l}\text { Informal or formal influences } \\
\text { Persuasion }\end{array}$ & $\begin{array}{l}\text { Internalisation of } \\
\text { established norms and } \\
\text { values through social or } \\
\text { peer networks }\end{array}$ \\
\hline $\begin{array}{l}\text { APPLIED TO } \\
\text { CORPORATE } \\
\text { SOCIAL } \\
\text { RESPONSIBILITY } \\
\text { REPORTING } \\
\text { (CSRR) }\end{array}$ & $\begin{array}{l}\text { Mining companies follow } \\
\text { the example of large } \\
\text { mining companies and } \\
\text { profitable mining } \\
\text { companies, such as BHP } \\
\text { Billiton }\end{array}$ & $\begin{array}{l}\text { CSRR in response to real or } \\
\text { anticipated pressure in the } \\
\text { environment, such as following } \\
\text { legislation or pre-empting } \\
\text { legislation, i.e. following IFRS, } \\
\text { corporate governance } \\
\text { guidelines, social responsibility } \\
\text { disclosure guidelines }\end{array}$ & $\begin{array}{l}\text { Management's MBA and } \\
\text { CA training combine with } \\
\text { consultants' shared } \\
\text { experiences with GRI, } \\
\text { leading to GRI } \\
\text { implementation and } \\
\text { institutionalisation }\end{array}$ \\
\hline \multirow{2}{*}{$\begin{array}{l}\text { ISOMORPHIC } \\
\text { FORCES } \\
\text { OPERATING } \\
\text { SIMULTANEOUSLY }\end{array}$} & $\begin{array}{l}\text { Mimetic influence could } \\
\text { lead to normative } \\
\text { influence }\end{array}$ & $\begin{array}{l}\text { Coercive influence could } \\
\text { lead to normative influence }\end{array}$ & \\
\hline & $\begin{array}{l}\text { Attributes arising from } \\
\text { copying leaders becomes } \\
\text { part of professional } \\
\text { standard of behaviour }\end{array}$ & $\begin{array}{l}\text { Demands from external } \\
\text { sources become recognized as } \\
\text { part of new professional } \\
\text { standard of behaviour }\end{array}$ & \\
\hline APPLIED TO CSRR & $\begin{array}{l}\text { BHP Billiton follows GRI. } \\
\text { Given their leadership in } \\
\text { the industry and in CSRR, } \\
\text { this may lead other } \\
\text { companies to start to view } \\
\text { GRI as the new } \\
\text { professional standard or } \\
\text { norm }\end{array}$ & $\begin{array}{l}\text { Various stakeholders demand } \\
\text { demonstration of corporate } \\
\text { social responsibility and the } \\
\text { response is to adopt existing } \\
\text { guidelines, e.g. GRI. In time, } \\
\text { following GRI might then } \\
\text { become the accepted norm }\end{array}$ & \\
\hline
\end{tabular}

In the sixth row of the table, we apply these ideas specifically to the field of mining CSRR. Thereafter, the table explains some possible interactions between isomorphic forces 
before providing examples of how both mimetic and coercive influences could lead to normative isomorphism.

In summary, companies adopt rules and structures, including CSRR patterns, to legitimise themselves. Global isomorphic pressures might lead to similar CSRR patterns, but differences in local social pressures on mining companies in Australia and South Africa might lead to different CSRR patterns.

\section{METHOD}

The major impact of company size and industry on CSRR is well known in the literature. We control for these factors by size matching mining companies. To ensure data availability and visibility, we include only listed companies and we exclude cross-listed companies to increase the likelihood that companies are only exposed to country-specific public pressures. There are more mining companies listed on the ASX than on the Johannesburg Securities Exchange (JSE). Thus, we start with mining companies listed only on the JSE. We match these 18 companies with companies listed only on the ASX, based on their market values using the exchange rate on 31 December 2007. The market capitalisations of the sample companies range, in Australian dollars, from $\$ 5.3$ million to $\$ 15,067$ million with a mean of $\$ 1,777$ million and a median of $\$ 720$ million.

We analyse the 36 companies' 2007 annual reports and websites (including standalone reports) during 2008, based on the GRI guideline categories and the disclosure items suggested by GRI and others combined with the sentence count method proposed by Hackston and Milne (1996). Separate CSR reports can typically be found on websites, thus we count these reports as part of website disclosures. In our analysis of websites, we do not follow links that lead away from the company website to other sites. We follow all links from the main website page and from there follow links that address the social and environmental 
issues we have identified (see below). We count sentences (including graphs, tables, etc.) and various quality characteristics of the sentences based on Hackston and Milne (1996), because managers decide how much they disclose (O’Dwyer, 2002) therefore volumes and characteristics are indications of the importance managers attach to certain topics and aspects of social and environmental issues in response to environmental pressures. These manager signals are ignored by research designs where a checklist of items is used. We record patterns and characteristics of disclosure and not the specific information, because prior research shows that mining companies do not report the same CSRR content in the same ways (Perez \& Sanchez, 2009; Jenkins \& Yakovleva, 2006). In the sentence count, we capture for each sentence whether it includes monetary information, other quantitative information, specific information (but non-quantitative), or is declarative in nature. In addition, we capture whether sentences represent good, bad or neutral news from the perspective of the company. This latter distinction follows Hackston and Milne (1996), e.g., a sentence describing environmental policy would be classified as a neutral environmental sentence; admitting to an environmental disaster, such as the collapse of a sludge dam, would be classified as "negative environmental"; and remediation would be classified as "positive environmental". This classification allows us to compare positive CSRR, which is likely to increase in response to bad news (Deegan \& Rankin, 1996). We are therefore able to compare both quantitative and qualitative aspects of the disclosure.

In the analysis, we include social and environmental disclosure items suggested by guidelines, namely the GRI G3 guideline including the mining sector supplement (2009a; 2009b); SustainAbility (2006); the International Institute for Environment and Development (2002) multi-stakeholder appraisal of sustainability in mining; and the International Council on Mining and Metals (2002). We also include disclosure items suggested in prior research (Deegan et al., 2002; Azapagic, 2004; Hackston \& Milne, 1996; Davis-Walling \& Batterman, 
1997; Milne, Tregidga, \& Walton, 2003). We aggregate disclosures in the GRI categories of environment, labour, society, and products. The GRI has corporate governance recommendations therefore we classify corporate governance disclosures into a separate category as part of social disclosures.

Milne and Adler (1999) found that even inexperienced content analysers can be relied on for aggregate disclosure analysis, but that they need to have coded at least 20 reports before their coding is reliable enough for detailed sub-categories. Our content analyser is highly experienced, having analysed 100 annual reports for a previous study by one of the authors using the Hackston and Milne (1996) method. In addition, one of the authors performed an audit on the analysis and, after discussion with the analyser, agreed with her interpretation on all issues raised.

We compare the number of sentences of Australian CSRR with the South African numbers by way of ANOVA. We first compare overall disclosure and then break down the disclosure into smaller categories and sub-categories. In this way, we are able to discern whether companies disclose on similar issues using similar characteristics of disclosure. In the broad category of social disclosure, our method may not be adequate to detect differences, but when the categories of social disclosure (labour practices, society, products, corporate governance) are compared individually, we expect differences to emerge, because e.g. South African CSRR would have to deal more extensively with the impact of worker health issues (recall the HIV/AIDS infection rates). Similarly environmental disclosure should not be too broad a category to find differences, because e.g. Australian CSRR would have to deal more extensively with the impact of environmental issues (recall the higher environmental group exposure).

In addition, we search for evidence of the three types of isomorphic forces in the specific CSRR content of our sample companies. We also search for evidence of similar 
CSRR management structures being used by companies, e.g., board and management committees, and individual job titles that signify involvement in CSRR. We follow this method because NIT would suggest that both CSRR itself and CSRR structures are legitimization devises and would be a response to the societal and institutional pressures experienced by companies.

Finally, we count and summarise sentences where CSRR refers to local regulations, issues and communities in our sample companies' annual reports. This analysis is designed to provide evidence of how local CSRR fit within the overall patterns identified.

\section{RESULTS}

\section{Sentence count results ${ }^{[3]}$}

We count the number of sentences of CSRR under various categories and we capture additional qualitative information regarding each sentence, in order to compare the CSRR patterns of mining companies in Australia and South Africa. The CSRR issues covered and the other characteristics of the sentences are compared to establish whether CSRR patterns are similar in the two countries or different, being driven by local social issues and pressures. Table 2, Panel A shows the overall results. The first comparison, i.e. the first row of figures in the table, shows the average market capitalisation of the Australian and the South African companies. As expected, due to the sample matching, the difference is small and not significant. Note that the two sets of companies in our sample are similar in terms of size and industry, the two indicators most consistently found in prior research to influence CSRR. Next, the average number of sentences of social disclosure each company had in both their annual reports and on their websites is compared. Also, the average number of sentences of environmental disclosure in all media is compared. South African companies might be expected to disclose more employment related issues and Australian companies to disclose 
more environmental information, in response to the differential prominence of relevant groups in the two countries. However, both comparisons show no statistical significance (with p-values above 0.6).

Table 2. Mining company's 2007 corporate social responsibility reporting (CSRR) in annual reports and on websites - characteristics

\begin{tabular}{|c|c|c|c|c|c|c|c|c|}
\hline \multirow{2}{*}{$\begin{array}{l}\text { Number of sentences (unless stated) } \\
\text { Panel A: Overall }\end{array}$} & \multicolumn{3}{|c|}{ Australia } & \multicolumn{3}{|c|}{ South Africa } & \multicolumn{2}{|c|}{ ANOVA } \\
\hline & Mean $^{3}$ & $\begin{array}{l}\text { Std } \\
\text { Dev }\end{array}$ & $\mathbf{n}$ & $\operatorname{Mean}^{3}$ & $\begin{array}{l}\text { Std } \\
\text { Dev }\end{array}$ & $\mathbf{n}$ & F-stat & $P$ value \\
\hline Size (market capitalisation ${ }^{2}$ ) AUS $\$$ million & $\begin{array}{r}1814.6 \\
57 \\
\end{array}$ & $\begin{array}{r}3615.1 \\
18 \\
\end{array}$ & 18 & $\begin{array}{r}1738.3 \\
18 \\
\end{array}$ & $\begin{array}{r}3615.4 \\
02 \\
\end{array}$ & 18 & 0.004 & 0.950 \\
\hline Social disclosure & $\begin{array}{r}279.33 \\
3 \\
\end{array}$ & $\begin{array}{r}196.97 \\
2 \\
\end{array}$ & 18 & $\begin{array}{r}334.66 \\
7 \\
\end{array}$ & $\begin{array}{r}433.72 \\
2 \\
\end{array}$ & 18 & 0.243 & 0.625 \\
\hline Environmental disclosure & 98.056 & $\begin{array}{r}126.85 \\
0 \\
\end{array}$ & 18 & $\begin{array}{r}120.27 \\
8 \\
\end{array}$ & $\begin{array}{r}169.83 \\
3 \\
\end{array}$ & 18 & 0.198 & 0.659 \\
\hline \multicolumn{9}{|c|}{ Panel B: Social disclosures by GRI disclosure category } \\
\hline Labour practices & $\begin{array}{r}210.61 \\
1 \\
\end{array}$ & $\begin{array}{r}156.58 \\
5 \\
\end{array}$ & 18 & $\begin{array}{r}219.77 \\
8 \\
\end{array}$ & $\begin{array}{r}298.05 \\
6 \\
\end{array}$ & 18 & 0.013 & 0.909 \\
\hline Society & 41.389 & 52.229 & 18 & $\begin{array}{r}105.76 \\
5\end{array}$ & $\begin{array}{r}141.56 \\
6\end{array}$ & 17 & $3.115^{1}$ & $0.093^{1}$ \\
\hline Products & 5.333 & 4.042 & 3 & 2.333 & 2.805 & 6 & 1.750 & 0.227 \\
\hline Corporate Governance & 26.444 & 43.176 & 18 & 14.222 & 10.957 & 18 & 1.355 & 0.252 \\
\hline \multicolumn{9}{|c|}{ Panel C: By Good, Bad, Neutral news from a company perspective } \\
\hline Social - good news & 31.944 & 21.217 & 18 & 58.056 & 69.778 & 18 & $2.307^{1}$ & $0.144^{1}$ \\
\hline Social - bad news & 5.750 & 3.334 & 12 & 8.929 & 9.683 & 14 & $1.325^{1}$ & $0.266^{1}$ \\
\hline Social - neutral news & $\begin{array}{r}243.55 \\
6 \\
\end{array}$ & $\begin{array}{r}182.92 \\
3 \\
\end{array}$ & 18 & $\begin{array}{r}269.66 \\
7 \\
\end{array}$ & $\begin{array}{r}360.13 \\
2 \\
\end{array}$ & 18 & 0.075 & 0.786 \\
\hline Environment - good news & 17.333 & 18.901 & 15 & 12.588 & 14.833 & 17 & 0.632 & 0.433 \\
\hline Environment - bad news & 5.857 & 7.988 & 7 & 9.500 & 11.263 & 8 & 0.507 & 0.489 \\
\hline Environment - neutral news & 81.333 & $\begin{array}{r}107.00 \\
4 \\
\end{array}$ & 18 & $\begin{array}{r}104.16 \\
7 \\
\end{array}$ & $\begin{array}{r}147.77 \\
3 \\
\end{array}$ & 18 & 0.282 & 0.599 \\
\hline \multicolumn{9}{|l|}{ Panel D: By disclosure medium } \\
\hline Social - Annual report & $\begin{array}{r}218.50 \\
0 \\
\end{array}$ & $\begin{array}{r}126.01 \\
9 \\
\end{array}$ & 18 & $\begin{array}{r}233.83 \\
3 \\
\end{array}$ & $\begin{array}{r}273.45 \\
7 \\
\end{array}$ & 18 & 0.047 & 0.830 \\
\hline - Social - Financial Statement & 71.944 & 52.352 & 18 & 59.294 & 79.180 & 17 & 0.314 & 0.579 \\
\hline - Social - Rest of Annual Report & $\begin{array}{r}146.55 \\
6 \\
\end{array}$ & $\begin{array}{r}100.02 \\
5 \\
\end{array}$ & 18 & $\begin{array}{r}177.83 \\
3 \\
\end{array}$ & $\begin{array}{r}198.73 \\
8 \\
\end{array}$ & 18 & 0.356 & 0.555 \\
\hline Social-Website & 84.231 & $\begin{array}{r}103.16 \\
9 \\
\end{array}$ & 13 & $\begin{array}{r}121.00 \\
0 \\
\end{array}$ & $\begin{array}{r}174.79 \\
7 \\
\end{array}$ & 15 & 0.441 & 0.513 \\
\hline Environment - Annual report & 44.278 & 51.961 & 18 & 84.882 & $\begin{array}{r}101.78 \\
3\end{array}$ & 17 & 2.247 & 0.143 \\
\hline - Environment - Financial Statement & 13.385 & 8.262 & 13 & 22.625 & 18.453 & 16 & $3.218^{1}$ & $0.087^{1}$ \\
\hline - Environment - Rest of Annual Report & 34.611 & 46.716 & 18 & 63.588 & 91.172 & 17 & 1.424 & 0.241 \\
\hline Environment - Website & 80.667 & $\begin{array}{r}126.94 \\
5 \\
\end{array}$ & 12 & 51.571 & 77.717 & 14 & 0.513 & 0.481 \\
\hline \multicolumn{9}{|l|}{ Panel E: By Quality scores ${ }^{4}$ (not sentences) } \\
\hline Social disclosures (quality scores ${ }^{4}$ ) & $\begin{array}{r}492.94 \\
4 \\
\end{array}$ & $\begin{array}{r}331.60 \\
0 \\
\end{array}$ & 18 & $\begin{array}{r}532.72 \\
2 \\
\end{array}$ & $\begin{array}{r}686.17 \\
6 \\
\end{array}$ & 18 & 0.272 & 0.605 \\
\hline Environmental disclosures (quality scores ${ }^{4}$ ) & $\begin{array}{r}145.22 \\
2 \\
\end{array}$ & $\begin{array}{r}201.67 \\
2 \\
\end{array}$ & 18 & $\begin{array}{r}182.83 \\
3 \\
\end{array}$ & $\begin{array}{r}229.98 \\
3 \\
\end{array}$ & 18 & 0.049 & 0.826 \\
\hline Panel F: Monetary, Quantitative, Specific & arative & & & & & & & \\
\hline
\end{tabular}




\begin{tabular}{|c|c|c|c|c|c|c|c|c|}
\hline Social - Monetary & 40.765 & 26.054 & 17 & 26.938 & 25.684 & 16 & 2.354 & 0.135 \\
\hline Social - Quantitative & 43.529 & 29.557 & 17 & 49.278 & 69.569 & 18 & 0.099 & 0.755 \\
\hline Social - Specific & 20.429 & 25.919 & 14 & 35.571 & 63.524 & 14 & 0.682 & 0.416 \\
\hline Social - Declarative & $\begin{array}{r}183.83 \\
3\end{array}$ & $\begin{array}{r}136.03 \\
6\end{array}$ & 18 & $\begin{array}{r}233.77 \\
8\end{array}$ & $\begin{array}{r}291.89 \\
0\end{array}$ & 18 & 0.433 & 0.515 \\
\hline Environment- Monetary & 5.462 & 5.043 & 13 & 16.000 & 13.221 & 16 & $8.622^{1}$ & $0.008^{1}{ }^{1}$ \\
\hline Environment- Quantitative & 48.500 & 48.661 & 6 & 16.375 & 19.639 & 8 & 2.920 & 0.113 \\
\hline Environment- Specific & 7.714 & 10.563 & 7 & 9.600 & 13.525 & 10 & 0.095 & 0.762 \\
\hline Environment- Declarative & 74.944 & 93.553 & 18 & 93.444 & $\begin{array}{r}140.45 \\
0 \\
\end{array}$ & 18 & 0.216 & 0.645 \\
\hline \multicolumn{9}{|c|}{$\begin{array}{l}{ }^{* * *} \text { Significant at the } 1 \% \text { level. } \\
{ }^{1} \text { F-stat and P-Value from Welch and Brown - Forsythe Test as Homogeneity of Variance test was significant. } \\
{ }^{2} \text { Market capitalisation figures are for } 31 / 12 / 07 \text {. } \\
{ }^{3} \text { The table reports the mean number of sentences disclosed by companies in various categories, unless otherwise stated. Means are based } \\
\text { on the number of companies disclosing (indicated), not the number of companies in the sample, explaining why sub-category means do } \\
\text { not necessarily add back to totals. }\end{array}$} \\
\hline
\end{tabular}

Even with this absence of overall differences, there may still be differences in the categories and characteristics. We evaluate the data in several different ways to find the differences and present these comparisons in Panels B-F.

In Panel B, social disclosures are split into the GRI categories, where South African companies might, e.g., be expected to disclose more labour-related information. None of the comparisons show significant differences. Note that the means reported in the table are based on the number of companies disclosing (indicated), not the number of companies in the sample. As a result, sub-category means do not necessarily add back to totals.

We also capture whether disclosures are good, bad or neutral news from a company perspective and compare both the social and the environmental disclosures along these lines in Panel C. We do this in view of Deegan and Rankin's (1996) finding that companies with particular environmental concerns disclose much more positive environmental information than a matched sample. Specifically, companies do not disclose the bad news, but disclose more unrelated good environmental news than similar companies with no bad environmental news (Deegan \& Rankin, 1996; see also De Villiers \& Van Staden, 2006 for a discussion). Therefore, we expect companies that experience more pressure from specific stakeholders to 
disclose more positive information regarding that particular stakeholder group's concerns, e.g. if environmental stakeholders pressurise Australian companies more, we expect Australian companies to disclose more positive environmental information. However, our results show no such differences.

The location where social or environmental information is disclosed could also differ between the countries, e.g., internet users as a percentage of the population, is $80.1 \%$ in Australia and $10.8 \%$ in South Africa (Internet World Stats, 2010). Therefore we compare where companies disclose and report the results in Panel D. Specifically, we split disclosures between financial statement disclosures, disclosures in the rest of the annual report, and those on websites. There are no significant differences. Note that the comparison for environmental disclosure in the financial statements yields a p-value of 0.087 ; however, we regard $5 \%$ as the cut-off point for significance.

Panel E shows a comparison of quality of disclosure scores. This entails weighting disclosures as follows: monetary disclosures sentences are multiplied by 4 , quantitative (but non-monetary) disclosures are multiplied by 3 , specific by 2 and declarative by 1 . Neither the social nor environmental disclosure quality score comparisons show a significant difference between the two countries.

The comparison in Panel E can potentially still hide differences because the quality scores are aggregated. In Panel F, the number of sentences of each quality type of disclosure is compared separately. The only significant difference among the 8 comparisons is between the average volume of monetary environmental information disclosed $(\mathrm{p}=0.008)$ by South African companies (16.00 sentences) and Australian companies (5.46 sentences). We will further discuss this difference below where we discuss normative isomorphism, professionalization, and Table 4. 
In summary, we compare 30 characteristics that measure the patterns of CSRR of Australian and South African mining companies, matched for size, and find only one statistically significant difference. Next, we provide specific examples of similar disclosures by Australian and South African companies, divided into the NIT derived categories of the three types of isomorphic forces and the management structures that support CSRR.

\section{Evidence of mimetic, coercive, and normative isomorphism (refer to Tables 3 and 4)}

Our NIT guiding framework leads us to specifically search for evidence of the three types of isomorphic forces. Bearing in mind that the three types of isomorphic forces generally operate simultaneously, we discuss each in turn.

Companies benchmark their activities and disclosures to others within their industry. Benchmarking is normally based on best practice. Since BHP Billiton is the largest mining company both in Australia and in South Africa and a leader in CSRR (Perez \& Sanchez, 2009), mining companies can be expected to follow their lead. This would be an example of mimetic isomorphism. In a specific example, both Australian company No. 18 and its South African counterpart in our sample have sustainability as the fifth main heading on their website homepage, as do BHP Billiton.

Coercive isomorphism refers to the influence of both compulsory rules and strong encouragement from powerful sources. The relevant institutional structures and rules that encourage or enforce similar disclosure behaviour in this instance are, accounting standards, stock exchange rules, corporate governance guidelines, and both environmental and disclosure legislation. IFRS accounting standards apply in both Australia and South Africa and influence CSRR, e.g., our CSRR measures in Table 2, Panel D (financial statement). Stock exchange rules, corporate governance guidelines, and disclosure legislation are also similar. For example, South African company No. 11 state in their sustainability report available on their website that: "The directors endorse the Code of Corporate Practices and 
Conduct (the Code) set out in King Report on Corporate Governance 2002 (King 2)." Australian company No. 18 state that their sustainability report: "includes information required under the ASX Corporate Governance Council's 'Corporate Governance Principles and Recommendation' (August 2007)." These statements illustrate coercive isomorphism in CSRR brought about by similar codes of conduct. Annual reports in both countries typically confirm compliance to the relevant code. Although these are 'corporate governance' codes, they both cover social and environmental issues and do so in similar fashion. There is also convergence of mandatory CSRR (e.g. environmental liabilities) where similar employment and environmental rules lead to similar liabilities that lead to similar disclosure. Similar rules also lead to similar concerns by shareholders, i.e. the cash flow impact of rules that managers address with voluntary CSRR.

The disclosure guidelines of the GRI are normative in nature and have gained influence due to their acceptance by professionals and consultants. For example, the professionalization of GRI implementation brought by the accounting profession has increased the likelihood of acceptance by companies (Mizruchi \& Fein 1999) and many of the larger companies in the world now follow GRI guidelines (KPMG, 2008, 2011), among them BHP Billiton. If mining companies in both Australia and South Africa follow GRI, practice converges. The GRI mining industry framework is contributing to "further standardisation" (Azapagic, 2004: 640). An example of this in our sample is Australian company No. 8 disclosing the statement: "This report has been prepared using the internationally recognised G3 Global Reporting Initiative (GRI) framework". A similar statement is disclosed in the matching South African Company No. 8 stating: "This report has been prepared using the Global Reporting Initiatives (GRI) Guidelines and the Mining and Metals Sector Supplement as a framework." Each company then use the same style in providing their GRI application level. The two companies also referred to stakeholders in the 
Table 3. Mining company's 2007 corporate social responsibility reporting (CSRR) in annual reports and on websites - some examples of similarities

\begin{tabular}{|c|c|}
\hline Australia & South Africa \\
\hline \multicolumn{2}{|l|}{ Similar CSRR disclosures } \\
\hline \multicolumn{2}{|l|}{ Mimetic } \\
\hline \multicolumn{2}{|l|}{ On websites } \\
\hline $\begin{array}{l}\text { Sustainability is the fifth main heading on their } \\
\text { website homepage - same as BHP Billiton }\end{array}$ & $\begin{array}{l}\text { Sustainability is the fifth main heading on their } \\
\text { website homepage - same as BHP Billiton }\end{array}$ \\
\hline \multicolumn{2}{|l|}{ Coercive } \\
\hline \multicolumn{2}{|l|}{ In their sustainability reports - on websites } \\
\hline $\begin{array}{l}\text { "....includes information required under the ASX } \\
\text { Corporate Governance Council's 'Corporate } \\
\text { Governance Principles and Recommendation } \\
\text { (August 2007)." }\end{array}$ & $\begin{array}{l}\text { "The directors endorse the Code of Corporate } \\
\text { Practices and Conduct (the Code) set out in } \\
\text { King Report on Corporate Governance } 2002 \\
\text { (King 2)." }\end{array}$ \\
\hline \multicolumn{2}{|l|}{ Normative } \\
\hline \multicolumn{2}{|l|}{ In their sustainability reports - on websites } \\
\hline $\begin{array}{l}\text { "This report has been prepared using the } \\
\text { internationally recognised G3 Global Reporting } \\
\text { Initiative (GRI) framework." }\end{array}$ & $\begin{array}{l}\text { "This report has been prepared using the Global } \\
\text { Reporting Initiatives (GRI) Guidelines and the } \\
\text { Mining and Metals Sector Supplement as a } \\
\text { framework." }\end{array}$ \\
\hline $\begin{array}{l}\text { use the same style in providing their GRI } \\
\text { application level }\end{array}$ & $\begin{array}{l}\text { use the same style in providing their GRI } \\
\text { application level }\end{array}$ \\
\hline $\begin{array}{l}\text { "This report aims to present our stakeholders } \\
\text { with information about our economic, } \\
\text { environmental and social performance." }\end{array}$ & $\begin{array}{l}\text { "This framework has been designed to provide } \\
\text { comprehensive information to stakeholders of } \\
\text { an organisation on economic, social and } \\
\text { environmental performance that make up its } \\
\text { triple bottom line." }\end{array}$ \\
\hline \multicolumn{2}{|l|}{ Similar CSRR rules and structures } \\
\hline \multicolumn{2}{|l|}{ In annual reports } \\
\hline $\begin{array}{l}\text { The Sustainability Committee's role is to } \\
\text { "facilitate and engender a culture of } \\
\text { sustainability" }\end{array}$ & $\begin{array}{l}\text { The Sustainability Committee's role is to ensure } \\
\text { that "effective measures, systems and controls } \\
\text { are in place for sustainability" }\end{array}$ \\
\hline $\begin{array}{l}\text { "The role of Head of Safety, Environment and } \\
\text { Risk has been created, reporting directly to the } \\
\text { Managing Director... The Managing Director } \\
\text { reports monthly to the Board on all } \\
\text { environmental and health and safety incidents" }\end{array}$ & $\begin{array}{l}\text { "Strategic direction for sustainable development } \\
\text { is managed at the corporate office level by the } \\
\text { safety and occupational health department, and } \\
\text { the sustainable development and environment } \\
\text { department." }\end{array}$ \\
\hline
\end{tabular}

same way, with Australian company No. 8 disclosing: "This report aims to present our stakeholders with information about our economic, environmental and social performance", and South African company No. 8 stating: "This framework has been designed to provide 
comprehensive information to stakeholders of an organisation on economic, social and environmental performance that make up its triple bottom line." Bearing in mind that these companies operate in countries with different social make-ups, these statements appear to be GRI inspired.

Normative isomorphism goes hand-in-hand with professionalization, specifically training and professional membership socialise individuals into common beliefs regarding what constitutes accepted norms. For example, MBA programmes teach similar norms; accounting bodies, such as chartered accounting and certified public accounting bodies encourage similar norms; and the same goes for other degree programmes and professions. Table 4, Panel A shows how common these professional memberships and degrees are among the directors and senior managers of the companies in our sample. The table also show how similar Australian and South African companies are in this respect. Note in particular how many CAs and CPAs there are, as well as how similar the numbers are between Australian and South African companies. There are also many MBAs, more so in South African companies. Nevertheless, 'MBA ideas' will still play an important part in Australian companies, as these individuals occupy leadership positions. The leadership of the Australian and South African companies in our sample are dominated by individuals with common educational backgrounds and professional memberships. These individuals are likely to share similar norms regarding a range of management topics, including a shared taken-for-grantedness regarding the appropriate treatment or norms around CSRR matters, including CSRR patterns. 
Table 4. Company characteristics that suggest professionalization

Panel A. Qualifications held by directors and senior managers as disclosed in annual reports

\begin{tabular}{|l|c|c|c|c|c|c|}
\hline Country & $\begin{array}{c}\text { CAs \& } \\
\text { CPAs }\end{array}$ & MBAs & $\begin{array}{c}\text { Acc } \\
\text { Degrees }\end{array}$ & $\begin{array}{c}\text { Business } \\
\text { Degrees }\end{array}$ & $\begin{array}{c}\text { Sci/Eng } \\
\text { Degrees }\end{array}$ & $\begin{array}{c}\text { Law } \\
\text { Degrees }\end{array}$ \\
\hline Australian & 36 & 10 & 2 & 4 & 40 & 15 \\
\hline South African & 31 & 25 & 7 & 21 & 57 & 18 \\
\hline
\end{tabular}

Each director and manager appears once in the table. Individuals with more than one qualification are included in the first applicable column from the left.

Panel B. Assurance services used as disclosed

\begin{tabular}{|l|c|c|c|c|c|c|}
\hline & \multicolumn{2}{|c|}{ Annual report assurance } & \multicolumn{2}{c|}{ CSRR assurance } & \multicolumn{2}{c|}{ Internal audit } \\
\hline Country & $\begin{array}{c}\text { BIG 4 } \\
\text { auditor }\end{array}$ & Other & $\begin{array}{c}\text { BIG 4 } \\
\text { auditor }\end{array}$ & Other & $\begin{array}{c}\text { BIG 4 } \\
\text { auditor }\end{array}$ & Other \\
\hline Australian & 10 & 8 & & 2 & 2 & \\
\hline South African & 14 & 4 & 2 & 2 & & \\
\hline
\end{tabular}

Table 4, Panel B shows the professional firms that provide both external and internal audit services to the firms in our sample, as disclosed. The table shows that the Big 4 audit firms play a major role, providing annual report assurance services to 24 out of the 36 companies in our sample. The Big 4 firms also provide some CSRR assurance services and some internal auditing services to a smaller number of companies in the sample. Professional accounting firms are leaders in providing CSRR consultancy and assurance services and actively try to grow this part of their business by offering these services to their clients (O’Dwyer et al., 2011). The CSRR solutions these accounting firms offer are likely to conform to preconceived norms and they thereby play a role in professionalising and standardising CSRR; which can, in institutional theory terms, be classified as normative isomorphism. 
Of course, we cannot entirely discount the possibility that companies adopt GRI not for normative reasons, but for strategic reasons. However, having said that, why would they have chosen GRI as a strategic tool, if not for the fact that following GRI is now seen as the norm?

We now return to the one statistically significant difference between the two countries (see Table 2), namely the fact that South African mining companies in our sample disclose a greater volume of monetary environmental information than their Australian counterparts. We posit that it is more likely for accountants, and Big 4 consultants and assurance providers, to focus on monetary disclosures than non-accountants. Table 4, Panel A shows that there are more individuals with accounting degrees among South African directors and senior managers; and Panel B shows that there are more Big 4 assurance providers among South African firms. Therefore, the greater influence of accounting socialization in South African firms correlates with greater monetary environmental disclosure. This provides some further evidence to support a claim of the professionalization of the field of CSRR.

In summary, specific examples of CSRR in the two countries provides evidence of mimetic, coercive, and normative isomorphism. These examples of similarities provide clues regarding managers' taken-for-granted belief systems regarding CSR and CSRR.

\section{Evidence of similar rules and structures}

NIT suggests that rules and structures are adopted to gain legitimacy; and rules and structures are the observable manifestations of taken-for-grated belief systems. Further evidence of isomorphism can be found in the disclosures of our sample companies that specifically relate to the adoption of similar CSRR board and management structures in the two countries. According to the disclosures, the board committees recommend CSRR policies and strategies; monitor and coordinate the implementation of these strategies; and advise on CSRR issues. The committees usually comprise of at least one independent director and a few members of the board with the CEO attending meetings. Specific examples are: 
(1) Carbon Committees whose role "is to ensure that adequate resources and systems are available to meet regulatory requirements" (Australian company No. 7).

(2) Safety, Health and Environment Committees where the common theme is to identify risks, evaluate policies and practices, monitor performance and ensure thorough incident investigations.

(3) Sustainability Committees whose role is to ensure that "effective measures, systems and controls are in place for sustainability" (South African company No. 9) and to "facilitate and engender a culture of sustainability" (Australian company No. 9).

Similar management structures is also revealed in annual reports, e.g., the creation and the expansion of responsibilities of management positions in order to manage social and environmental issues, such as the General Manager for Human Resources title being changed to General Manager, Human Resources and Sustainability to reflect the increased focus on sustainability (their word, not ours) and the attendant risks. In specific examples, Australian Company No. 18 state that "The role of Head of Safety, Environment and Risk has been created, reporting directly to the Managing Director... The Managing Director reports monthly to the Board on all environmental and health and safety incidents", whereas the matched South African Company No. 18 indicated that "Strategic direction for sustainable development is managed at the corporate office level by the safety and occupational health department, and the sustainable development and environment department." The specific examples show that similar management and board structures are used in both countries to manage social and environmental issues. These structures influence CSRR rules and practice, as well as being legitimating. 
In summary, we find evidence that companies in two diverse settings use similar CSRR and similar internal CSRR structures. NIT would suggest that both disclosure and disclosure structures are used by companies in order to legitimise.

\section{Evidence of differences in CSRR related to local regulations, issues, and communities}

We have thus far focussed on similarities in the structure of CSRR in Australia and South Africa. We now turn to differences in local content. Note that the examples, summarised in Table 5, fit within the similar overall structure of disclosure that we have discussed before.

Table 5. Mining companies' 2007 corporate social responsibility reporting (CSRR) in annual reports - a summary of differences related to local regulations, issues, and communities

\begin{tabular}{|c|c|c|}
\hline & AUSTRALIA & SOUTH AFRICA \\
\hline & $\begin{array}{l}\text { Number of Sentences } \\
\text { (Number of companies) }\end{array}$ & $\begin{array}{l}\text { Number of Sentences } \\
\text { (Number of companies) }\end{array}$ \\
\hline Local stock exchange rules & ASX $\quad 40(16)$ & JSE $\quad 36(6)$ \\
\hline King Report - Code of Corporate Practices & - & $50(12)$ \\
\hline Environmental regulation & $13(5)$ & $9(3)$ \\
\hline Local companies' act & $20(3)$ & $8(3)$ \\
\hline Local Communities & $91(5)$ & $67(7)$ \\
\hline Empowerment & Aboriginal $46(8)$ & BEE* $125(12)$ \\
\hline $\begin{array}{l}\text { Historically Disadvantaged South Africans } \\
\text { (HDSA) }\end{array}$ & - & $110(7)$ \\
\hline Equality - women & $4(2)$ & $67(8)$ \\
\hline Photos & Women & Blacks $13(6)$ \\
\hline HIV/AIDS & - & $24(5)$ \\
\hline
\end{tabular}

Companies often refer to the stock exchange rules that relate to CSRR, with 16 Australian companies referring to ASX listing rules and six South African companies to JSE listing rules. The JSE also requires adherence to the King Report on Corporate Governance, a code which emphasises social and environmental issues, and 12 out of the 18 companies in the sample mention this code in their annual reports. Similar numbers of companies in the 
two countries mention local environmental legislation and the local companies' act. Local communities are also mentioned by similar numbers of companies in both countries.

Mining companies in the two countries provide a large amount of information focussed on the specific needs of disadvantaged population groups. For example, Australian companies emphasise aboriginals in their empowerment-related disclosures, whereas 12 out of the 18 South African companies mention Black Economic Empowerment (BEE), the official government policy. Other South African companies refer to historically disadvantaged South Africans, being a more inclusive term than blacks. South African companies (8/18) address gender equality, but interestingly, an analysis of the photographs in annual reports reveals that Australian companies tend to depict women, whereas South African companies by and large depict black men. The issue of HIV/AIDS, mentioned earlier, was explicitly addressed in five of the South African companies' annual reports.

Overall, companies in the two countries address many local issues in their CSRR within the similar overall structures we identified earlier. However, it should be noted that referring to the specific needs of local aboriginals in Australia as opposed to local blacks in South Africa do not change the overall structure of CSRR, with similar volumes (or emphases) devoted to major topic areas.

\section{DISCUSSION AND IMPLICATIONS}

Our findings show the overall characteristics of CSRR (i.e. CSRR patterns or report structures), specific examples of CSRR, and the CSRR management structures of Australian and South African mining companies to be similar. These similarities appear to be driven by isomorphic pressures, i.e. companies copy others, are pressurised to adopt, and through the professionalization of CSRR, willingly adopt general (global) solutions to respond to environmental pressures. ${ }^{[4]}$ We show in Table 5 that companies do not disclose identically at the detailed level, e.g. they differ by referring to local rules, codes, laws, and stakeholders. 
But companies appear to be using the same overall CSRR framework and structure (i.e. CSRR patterns), sometimes down to similarities in detailed aspects of CSRR disclosure and management. These similarities could easily be dismissed as unremarkable, unless we consider the situation in the 1980s and 1990s when both CSRR content and patterns were much more varied than our findings suggest the case to be now.

\section{Further implications}

Our findings show CSRR patterns and governance structures of CSRR to be similar. Companies appear to implement international solutions, perhaps to deflect local concerns. Companies take their cues from their peers (mimetic), and from institutional structures, such as the capital markets and the rules that govern them (coercive isomorphism). These structures can be remarkably similar in completely different settings (Rahaman, Lawrence, \& Roper, 2004). Cormier and Magnan (2003: 58) mention that, despite different socio-cultural environments, the globalised stock markets foster convergence between various country's corporate practices. Companies increasingly follow the GRI guidelines (KPMG, 2008, 2011). These guidelines are normative in nature and if companies adopt GRI because they think it is the right thing to do, especially if this is driven by the professionalization of the field of CSRR through manager training and consultant interaction, then the adoption of GRI can be seen as a form of normative isomorphism. Delmas (2002) predicts that a standard that could clearly spell out a procedure for stakeholders to assess environmental performance within and across countries would diffuse more quickly internationally. The GRI guideline is such a standard and is taking a leading role among CSRR standards. The three types of isomorphic forces collectively influence the CSRR practices and patterns adopted by companies worldwide, with normative isomorphism becoming more important as the field matures and becomes more professionalized, as suggested by NIT (DiMaggio \& Powell, 1983; Suddaby \& Viale, 2010). Bebbington, Larrinaga, and Moneva, (2009: 595) also see CSRR as becoming 
institutionalized through the convergence of various regulative, normative, and cognitive (organisations using mimicry for competitive reasons) institutions. Our results are consistent with these notions.

Our results show evidence in support of the application of NIT to CSRR we made in Table 1 and suggest normative isomorphism to be important in shaping contemporary CSRR, while mimicry and coercive processes are also still prevalent. Norms and procedures, that were previously unique to the leaders in CSRR, have now become institutionalised by way of corporate structures around frameworks like the GRI, and may have become resistant to change.

GRI is an example of a template in the CSRR field. Isomorphism by template is not unexpected by structuralists in highly professionalized settings (Heugens \& Lander, 2009:63, Tolbert \& Zucker, 1983; Giddens, 1984; Fligstein, 1985; Edelman, 1990). However, Tuttle and Dillard (2007:390) express concern that templates cause "the institutionalized practices and norms [to] become generally accepted without serious questioning as to their relevance in particular instances". In the case of CSRR, these particular instances can be seen as local social issues as reflected by local stakeholder needs and concerns. Templates are used to legitimise, however this is not necessarily achieved by systematically engaging with stakeholders and responding to their concerns, but by a less costly and less relevant process of adopting global disclosure templates. The fear is that, as Heugens and Lander (2009) hypothesise, the use of templates increases symbolic performance (measured by regulatory and media endorsements), but decreases substantive performance. ${ }^{[5]}$ Note that the adoption of templates, such as the GRI, does not necessarily have to lead to reduced stakeholder engagement. Companies can still deal with specific local concerns within the overall global framework adopted, however following an international disclosure framework could potentially obscure a relative lack of meaningful stakeholder engagement. 
GRI G3, in force at the time, prompts companies to state the GRI level of reporting they have reached. Managers are thus encouraged to start with less onerous (level C) reporting and then to improve their standing in subsequent years by progressing to the $\mathrm{B}$ and eventually the A level. When management by "league table" takes over, managers focus on improving their league table standing and not on managing the underlying issue (Tsoukas, 1997). This management of GRI standing therefore potentially shifts the focus from socially responsible action and reporting on these actions, to increasing the company's GRI reporting level, i.e. increasing the number of CSRR boxes that can be ticked.

These templates, "league table" management, and box ticking tendencies, imply that CSRR is internally focussed (despite claims of stakeholder engagement) and in this way similar to other areas of management.

Our results suggest global convergence in CSRR patterns. At the company level, managers appear to be using global templates to shape their CSRR. At the level of the field of CSRR, the now institutionalized use of global CSRR patterns appears to indicate that the field is maturing and professionalising. This implies that an increased volume of CSRR is not necessarily indicative of elevated social and environmental intentions or performance. Within the global template or CSRR pattern, managers add a local flavour to their CSRR content by referring to local rules (e.g. by referring to the relevant local corporate governance code) and local stakeholders (e.g. by referring to the relevant local communities). Therefore, an important finding of this study is that managers appear to shape their CSRR content to fit a predetermined CSRR pattern.

\section{CONCLUSION}

We compare 30 characteristics of the CSRR (i.e. CSRR patterns) of a size matched sample of Australian and South African mining companies in their annual reports and on their 
websites. Thus our two sets of companies are similar for the two characteristics that prior research has consistently found to be most influential in CSRR, but the companies are subject to different social and environmental issues, and different pressure groups in the two countries. We find only one statistically significant difference (at the $1 \%$ or the $5 \%$ level) among the 30 comparisons, suggesting similar CSRR patterns in the two countries. We also quote specific disclosures to demonstrate: the similarity in CSRR, and similarities in CSRR management and board structures. We find Australian and South African mining company CSRR structures to be remarkably similar. We conclude that the structure of CSRR is subject to isomorphic pressures related to the similarities in institutional environments and capital markets (see e.g. Unerman \& Bennett, 2004). Specifically, with benchmarking (mimetic) being a widespread business practice, mining companies in both countries can pattern their disclosure on BHP Billiton, as their largest peer. Coercive isomorphism plays a role by way of similar accounting rules, stock exchange rules, corporate governance rules, and the structure of the capital markets in the two countries. These rules influence CSRR directly by addressing social and environmental issues, and indirectly, by focussing shareholder attention on certain areas. If the increased adherence to the GRI guidelines (see KPMG, 2008, 2011) is due to, or partly due to the professionalization of the field of CSRR, the GRI guidelines can be classified as a normative isomorphic pressure that influences convergence in CSRR among companies from different countries. The NIT literature (DiMaggio \& Powell, 1983; Tuttle \& Dillard, 2007) suggests that as a field matures, normative isomorphism becomes increasingly important. Therefore, CSRR appears to be moving in the direction of maturity.

Managers apparently use CSRR templates (e.g. GRI) that were developed independent of local issues and concerns. The use of templates (or global patterns) may increase symbolic performance, by companies being able to tick more disclosure (or GRI) boxes, without necessarily increasing substantive social and environmental performance (Heugens \& Lander, 
2009). We provide evidence that the global CSRR patterns are infused with local CSRR content with, e.g., references to local rules, and communities. However, without the adoption of global CSRR patterns, local CSRR patterns might have developed in completely different directions. For example, the volume of social versus environmental sections may have been different in two countries. Given the move towards global CSRR patterns, the implication is that a greater volume of CSRR is not necessarily indicative of management intent regarding social and environmental issues.

Our contribution to CSRR theorizing is that we suggest that in the interpretation of CSRR, the reader (user, researcher, regulator) should assume that the disclosures are based on global templates and that the volume of contents are not necessarily indicative of management intent or of company-specific characteristics, such as actual (social and environmental) performance. If CSRR comes to share a global template because managers are shaping the form or volume of content to fit the template, the implication for researchers is that counting total words, sentences or pages of environmental or social disclosure will be less and less relevant as an indication of manager's intent and concern. By way of a contribution to the institutional theory literature, we offer firstly the distinction between global versus local (or country-specific) levels of field (referring to field-level change here), and secondly strong evidence of global institutions (in the pattern of CSRR) being used in diverse settings. Our evidence is strong, because CSRR constitutes highly visible attempts to influence legitimacy, making it less susceptible to incorrect description or misinterpretation.

\section{Limitations}

We acknowledge that our findings may not be generalizable beyond the mining industry. In any study of this nature, characteristics and patterns of disclosure are compared. Similar to other studies, our method of capturing and comparing disclosures can be a limitation. One of the South African companies in our sample, Exxaro, has a relatively minor 
part of its operations in Australia. This may have influenced Exxaro's CSRR. However, we

are confident that such possibilities do not detract from the central conclusion of this paper,

namely that CSRR has to a large extent standardised in terms of disclosure patterns and in

terms of management structure across national borders.

\section{NOTES}

[1] Corporate social responsibility reporting (e.g., Bebbington et al., 2008) is also called sustainability reporting (e.g., Gray, 2010) and can be defined as disclosures by companies of any aspect related to their impact on society or the natural environment.

[2] We have to acknowledge that Australian trade unions are also strong and could be in a position to influence disclosure. However, the point we are making here is that disclosures might be expected to be different in the two countries.

[3] Hooks and Van Staden (2011) show that sentence counts and quality scores of environmental CSRR are highly correlated. In addition, we provide the following example as evidence that our sentence count method is appropriate in discerning CSRR differences. One of the companies in our sample disclosed only two environmental sentences in (the rest of) their annual report, namely: "The objective of [the company] is to increase the value of the Company's mineral assets for the benefit of all stakeholders in a socially and environmentally responsible manner. The Company is firmly committed to the conservation of the environment with the goal of minimising risks through a process of planning and consultation with local communities." These sentences are general in nature. The matched company disclosed 62 environmental sentences, the first two being similarly general in nature: "[The company] prides itself in recognising the biodiversity, ecological significance, and heritage value of the natural areas under its influence. We recognise that in order to be an economically successful company, efficient environmental performance and understanding must be integrated into all aspects of our Company's activities." Several pages then follow explaining the environmental management activities and programmes in detail. In these disclosures, the two companies deal with general environmental issues in much the same way in the initial two sentences. If the second company only disclosed the first two sentences, the two companies' environmental disclosure would have been similar and our method would have reflected this. However, the second company disclose much more detail in the 60 additional sentences, and our method reflects the difference.

[4] An alternative explanation for the similarities may be that although Australia and South Africa are dissimilar in income, health and employment statistics, corporate annual reports and websites could still be aimed at similar audiences, namely sophisticated capital market participants. This argument takes the stance that the other stakeholders are ignored by CSRR. However, prior research suggests that CSRR tends to increase along with environmental NGO membership, which reflects social concerns (Deegan \& Gordon, 1996), media attention, reflecting social concerns, influences environmental disclosure (Brown \& Deegan, 1998), and environmental NGOs specifically influence minerals industry disclosures (Deegan \& Blomquist, 2006). In addition, websites are generally regarded as an avenue to communicate with other stakeholder groups, not exclusively shareholders (De Villiers \& Van Staden, 2011; Tilt, 2008), so website disclosures in the two countries should be different. Even if CSRR was only for shareholders, these disclosures would still have to deal with the issues of interest to shareholders, namely the influence of social and environmental issues on present and future cash flows. Therefore, even if shareholders are the only intended audience, South African CSRR would have to deal more extensively with the impact of worker health issues (recall the HIV/AIDS infection rates) and Australian CSRR would have to deal more extensively with the impact of environmental issues (recall the higher environmental group exposure). Therefore, we find this alternative explanation for our results unlikely.

[5] Heugens and Lander (2009) hypothesise that templates increase symbolic, but decrease substantive performance. They define substantive performance as accounting profit and find that profit increases with the use of templates. For our purpose here, we would define substantive performance as a function of real social and environmental actions. 


\section{REFERENCES}

Ader, C. R. (1995). A longitudinal study of agenda setting for the issue of environmental pollution. Journalism \& Mass Communication Quarterly, 72(2), 300-311.

Aerts, W., Cormier, D., Magnan, M. (2006). Intra-industry imitation in corporate environmental reporting: An international perspective, Journal of Accounting and Public Policy, 25, 299331.

Avert. (2009). HIV and AIDS in South Africa, available on the internet at: http://www.avert.org/aidssouthafrica.htm. Accessed 19.08.09.

Azapagic, A. (2004). Developing a framework for sustainable development indicators for the mining and minerals industry. Journal of Cleaner Production, 12(6), 639-662.

Bebbington, J., Higgins, C., Frame, B. (2009). Initiating sustainable development reporting: evidence from New Zealand. Accounting, Auditing \& Accountability Journal, 22(4), 588-625.

Bebbington, J., Larrinaga, C., Moneva, J. M. (2008). Corporate social reporting and reputation risk management. Accounting, Auditing \& Accountability Journal, 21(3), 337-361.

Brown, N., Deegan, C. (1998). The public disclosure of environmental performance information a dual test of media agenda setting theory and legitimacy theory. Accounting and Business Research, 29(1), 21-41.

Clarkson, P. M., Li, Y., Richardson, G. D., Vasvari, F. P. (2008). Revisiting the relation between environmental performance and environmental disclosure: An empirical analysis. Accounting, Organizations and Society, 33(3), 303-327.

Cormier, D., Magnan, M. (2003). Environmental reporting management: a continental European perspective. Journal of Accounting and Public Policy, 22, 43-62.

Cowen, S. S., Ferreri, L. B., Parker, L. D. (1987). The impact of corporate characteristics on social responsibility disclosure: A typology and frequency-based analysis. Accounting Organizations and Society, 12(2), 111-122.

Dacin, M. T. (1997). Isomorphism in context: The power and prescription of institutional norms. Academy of Management Journal, 40(1), 46-81.

Davis-Walling, P., Batterman, S. A. (1997). Environmental reporting by the Fortune 50 firms. Environmental Management, 21(6), 865-875.

De Klerk, M., De Villiers, C. (2012). The value relevance of corporate responsibility reporting: South African evidence. Meditari Accountancy Research, 20(1): 21-38.

De Villiers, C., Van Staden, C. (2006). Can less environmental information be legitimising? Evidence from Africa. Accounting, Organizations \& Society, 31(8), 763-781.

De Villiers, C., Van Staden, C. (2011). Where firms choose to disclose voluntary environmental information. Journal of Accounting and Public Policy, 30(6): 504-525.

Deegan, C., Blomquist, C. (2006). Stakeholder influence on corporate reporting: An exploration of the interaction between the World Wide Fund for Nature and the Australian minerals industry. Accounting, Organizations and Society, 31(4-5), 343-372.

Deegan, C., Gordon, B. (1996). A study of the environmental disclosure practices of Australian corporations. Accounting and Business Research, 26(3), 187-199.

Deegan, C., Rankin, R. (1996). Do Australian companies report environmental news objectively? An analysis of environmental disclosures by firms prosecuted successfully by the environmental protection authority, Accounting, Auditing \& Accountability Journal, 9(2), 5067.

Deegan, C., Rankin, M., Tobin, J. (2002). An examination of the corporate social and environmental disclosures of BHP from 1983-1997. A test of legitimacy theory. Accounting, Auditing \& Accountability Journal, 15(3), 312-343.

Deephouse, D. L. (1996). Does isomorphism legitimate?. Academy of Management Journal, 39(4), 1024-1039. 
Delmas, M. A. (2002). The diffusion of environmental management standards in Europe and in the United States: An institutional perspective. Policy Sciences, 35, 91-119.

DiMaggio, P. J., Powell, W. W. (1983). The iron cage revisited: Institutional isomorphism and collective rationality in organizational fields. American Sociological Review, 48, 147-160.

Edelman, L. B. (1990). Legal environments and organizational governance: The expansion of due process in the American workplace. American Journal of Sociology, 95, 1401-1440.

Fligstein, N. (1985), The spread of the multidivisional form among large firms, 1919-1979. American Sociological Review, 50, 377-391.

Georgakopoulos, G., Thomson, I. (2008). Social reporting, engagements, controversies and conflict in an arena context. Accounting, Auditing \& Accountability Journal, 21(8), 11161143.

Giddens, A. (1984). The Constitution of Society: Outline of the Theory of Structuration. Cambridge, UK: Polity Press.

Glennie, M., Lodhia, S. (2013). The influence of internal organisational factors on corporatecommunity partnership agendas: An Australian case study. Meditari Accountancy Research, 21(1): 52-67.

Gray, R. (2010). Is accounting for sustainability actually accounting for sustainability... and how would we know? An exploration of narratives of organisations and the planet. Accounting, Organizations and Society, 35(1), 47-62.

Gray, R., Owen, D., Adams, C. A. (1996). Accounting and Accountability: Changes and Challenges in Corporate Social and Environmental Reporting. London: Prentice Hall.

GRI. (2009a). Sustainability Reporting Guidelines, available on the internet at: www.globalreporting.org/NR/rdonlyres/ED9E9B36-AB54-4DE1-BFF25F735235CA44/0/G3_GuidelinesENU.pdf. Accessed 19.08.09.

GRI. (2009b). The GRI guidelines: An executive summary, available on the internet at: www.globalreporting.org/NR/rdonlyres/CF868D62-21F2-40DF-B090F061BBB4AC3B/0/G3_Executive_Summary.pdf. Accessed 19.08.09 .

Hackston, D., Milne, M. J. (1996). Some determinants of social and environmental disclosures in New Zealand companies. Accounting, Auditing \& Accountability Journal, 9(1), 77-108.

Haveman, H. A. (1993). Follow the leader: Mimetic isomorphism and entry into new markets. Administrative Science Quarterly, 38(4), 593-627.

Heugens, P., Lander, M. (2009). Structure! Agency! (And other quarrels): A meta-analysis of institutional theories of organization. Academy of Management Journal, 52(1), 61-85.

Hooks, J., Van Staden, C. J. (2011). Evaluating environmental disclosures: the relationship between quality and extent measures. British Accounting Review, 43(3), 200-213.

HRM Guide. (2009). Australian unemployment, available on the internet at: www.hrmguide.net/australia/jobmarket/employment.htm. Accessed 19.09.09.

ICMM. (2002). ICMM Sustainable Development Framework-ICMM Principles, International Council on Mining and Metals, London, available on the internet at: www.icmm.com/publications/ICMM_Principles_en.pdf. Accessed 19.08.09.

IIED. (2002). Breaking New Ground, International Institute for Environment Development. London: Earthscan.

Internet World Stats. (2010). Internet world stats: Usage and population statistics, available on the internet at: http://www.internetworldstats.com. Accessed 19.10.10.

Jenkins, H., Yakovleva, N. (2006). Corporate social responsibility in the mining industry: exploring trends in social and environmental disclosure. Journal of Cleaner Production, 14, 271-284.

KPMG. (2006). Global mining reporting survey, available on the internet at: www.kpmg.ca/en/industries/enr/mining/documents/GMS2006_PRINTversion_midres.pdf. Accessed 25.08.09. 
KPMG. (2008). International survey of corporate responsibility reporting, KPMG International, available on the internet at: www.kpmg.com. Accessed 3.05.09.

KPMG. (2011). Corporate Responsibility Survey 2011: Marching towards embracing sustainable development, KPMG International, available on the internet at: https://www.in.kpmg.com/SecureData/aci/Files/Corporate-Responsibilty-Survey-Report.pdf. Accessed 18.06.11.

Lawrence, S. R., Botes, V., Collins, E., Roper, J. (2013). Does accounting construct the identity of firms as purely self-interested or as socially responsible? Meditari Accountancy Research, 21(2): 144-160.

Milne, M. J., Adler, R. W. (1999). Exploring the reliability of social and environmental disclosures content analysis. Accounting, Auditing \& Accountability Journal, 12(2), 237-256.

Milne, M. J., Tregidga, H., Walton, S. (2003). The triple bottom line: benchmarking New Zealand's early reporters. University of Auckland Business Review, 5(2), 37-48.

Minerals Council of Australia. (2009). Fact sheet, available on the internet at: http://www.minerals.org.au/. Accessed 19.08.09.

Mizruchi, M. S., Fein, L. C. (1999). The social construction of organizational knowledge: A study of the users of coercive, mimetic, and normative isomorphism. Administrative Science Quarterly, 44, $653-683$.

Neu, D., Warsame, H., Pedwell, K. (1998). Managing public impressions: Environmental disclosures in annual reports. Accounting, Organizations and Society, 23(3), 265-282.

O'Dwyer, B. (2002). Managerial perceptions of corporate social disclosure, an Irish story. Accounting, Auditing \& Accountability Journal, 15(3), 406-436.

O’Dwyer, B., Owen, D., Unerman, J. (2011). Seeking legitimacy for new assurance forms: The case of assurance on sustainability reporting. Accounting, Organizations and Society, 36(1), 31-52.

Patten, D.M. (2002). Media exposure, public policy pressure, and environmental disclosure: An examination of the impact of tri data availability. Accounting Forum, 26(2), 152-171.

Perez, F., Sanchez, L. E. (2009). Assessing the evolution of sustainability reporting in the mining sector. Environmental Management, 43, 949-961.

Rahaman, A. S., Lawrence, S., Roper, J. (2004). Social and environmental reporting at the VRA: institutionalised legitimacy or legitimation crisis? Critical Perspectives on Accounting, 15, 35-56.

Samkin, G. (2012). Changes in sustainability reporting by an African defence contractor: a longitudinal analysis. Meditari Accountancy Research, 20(2): 134-166.

Schaltegger, S., Gibassier, D., Zvezdov, D. (2013). Is environmental management accounting a discipline? A bibliometric literature review. Meditari Accountancy Research, 21(1): 4-31.

Schepers, D. H., (2006). The impact of NGO network conflict on the corporate social responsibility strategies of multinational corporations. Business and Society, 45(3), 282-299.

Statistics South Africa. (2009). Stats online, available on the internet at: www.statssa.gov.za/keyindicators/keyindicators.asp. Accessed 19.08.09.

Suddaby, R., Viale, T. (2011). Professionals and field level change: Institutional work and the professional project. Current Sociology, 59(4), 423-442.

SustainAbility. (2006). Report assessment methodology - Global Reporters 2006, available on the internet at:

www.sustainabilty.com/downloads_public/insight_reports/GR_Methodology.pdf. Accessed 31.08.09.

The International Marketing Council (IMC) of South Africa. (2009). South Africa. Info, available on the internet at: www.southafrica.info/business/economy/sectors/mining.htm. Accessed 28.01.10. 
Tilt, C. A. (1994). The influence of external pressure groups on corporate social disclosure some empirical evidence., Accounting, Auditing \& Accountability Journal, 7(4), 47-72.

Tilt, C. A. (2008). Environmental disclosure outside the annual report. International Journal of Management and Decision Making, 9(3), 288-309.

Tolbert, P. S., Zucker, L. G. (1983). Institutional sources of change in the formal structure of organizations: The diffusion of civil service reform, 1880-1935. Administrative Science Quarterly, 28, 22-39.

Tsoukas, H. (1997). The tyranny of light: The temptations and the paradoxes of the information society. Futures, 29(9), 827-843.

Tuttle, B., Dillard, J. (2007). Beyond competition: Institutional Isomorphism in U.S. Accounting research. Accounting Horizons, 21(4), 387-410.

Unerman, J., Bennett, M. (2004). Increased stakeholder dialogue and the internet: towards greater corporate accountability or reinforcing capitalist hegemony? Accounting Organizations and Society, 29, 685-707.

World Bank. (2009).Country classification table, available on the internet at web.worldbank.org/WBSITE/EXTERNAL/DATASTATISTICS/0,,contentMDK:20420458 menuPK:64133156 pagePK:64133150 piPK:64133175 theSitePK:239419,00.html. Accessed 19.08.09. 